\title{
Development and Validation of Specific Chemistry Teaching Mode for Environmental Sustainability
}

\author{
Army Auliah $^{1}$, Muharram $^{2}$ \\ \{auliaarmy@ymail.com ${ }^{1}$, muharram_pasma@yahoo.com² ${ }^{2}$ \} \\ Universitas Negeri Makassar, Jalan Mallengkeri, Makassar 90224, Indonesia
}

\begin{abstract}
The importance of improving the quality of learning in schools is more and more recognized. Now day Green Chemistry is recommended in teaching chemistry as an effort to foster students' caring attitudes towards the environment. On the other hand, improving teaching quality through a lesson study has been done a lot. This paper contributes a solution to the problem of improving the quality of chemistry teaching that fosters students' caring attitudes towards the environment. The integration of the principles of green chemistry through the application of the principles of Lesson Study learning community that allows the principles of green chemistry to be understood and applied by students in their daily lives results in a Teaching model called Green Chemistry Learning Comprehensive by Collaborative and Collegialities (GCLC2C) that has been developed and validated.
\end{abstract}

Keywords: Chemistry Teaching Model, Lesson Study, Green Chemistry

\section{Introduction}

The dimensions of sustainable development focus on three main areas, namely environmental, economic, and social. Since the issue of sustainability emerged around the end of the twentieth century [1,2], various efforts have been made to achieve this. Sustainable development in the environmental field has been striving in every sector of development, including the education and learning sector.

Chemistry education and learning that lead to environmental sustainability are known as green chemistry. Green Chemistry refers to twelve very specific chemical practice principles [3, 4]. These twelve principles have the potential to achieve environmental sustainability. Therefore it is necessary to attempt to apply the principle. This has been done through the introduction of green chemistry in learning and research $[5,6]$.

In addition, the concept of green chemistry has been recommended for inclusion in the chemistry education curriculum [7,8]. Various studies supporting this have also been reported $[9,10]$. Creating a Sustainable Future through Education and Teaching Chemistry laden ethics is also reported [11].

Various studies relating to the application of green chemistry as an effort for environmental sustainability have been carried out $[12,13,14,15]$, but the phenomenon of environmental crisis is still being found, especially with regard to chemistry. This shows that the knowledge of green chemistry for chemical industry practitioners has not been implemented or understood yet. Understanding the principles of green chemistry enables application in life. This research 
answers this expectation by developing a learning model specifically for learning chemistry in achieving environmental sustainability.

This research is important, to provide instructions for teachers as steps that are packaged as a model to apply green chemistry in learning chemistry. As stated by [16, 17], Chemistry teachers or instructors as the spearhead in implementing environmentally friendly chemistry learning, need to have knowledge and skills in applying the principles of Green Chemistry. Another advantage of this research is the integration of the principles of green chemistry in learning using the principles of "Lesson Study Learning Community" allows teachers and students to understand concepts that are learned permanently.

\section{Research Method}

The development and validation of the Green Chemistry Learning Model -based on "Lesson Study Learning community" was carried out through two steps, namely: (1) Model development based on the steps of developing the Plomp model [18] and (2) Assessment of the model based on experts.

\subsection{Development of draft green chemistry learning model-based on "lesson study learning community"}

The phases of developing the model that follow the development phases of the general model of solving educational problems proposed by Plomp have been modified. Modification of the development phases is carried out by incorporating elements of the learning model proposed by $[19,20]$.

The design of the model is based on an analysis of the integration of the principles of green chemistry that have been carried out in the initial investigation phase. The results of the initial investigation were discussed in an expert forum as the "Lesson Study Learning Community" steps. In this phase, it has been found that many chemistry learning strategies integrate the principles of green chemistry in learning as stated in the introduction, but there is no specific model for making students really understand the principles of green chemistry. Therefore in this design, the principles of green chemistry are integrated into learning through the principles of the "Lesson Study Learning Community" that makes students understand exactly what they are learning.

Furthermore, the realization of the Model which was developed includes: (a) designing learning syntax that considers the acquisition of student knowledge meaningfully or comprehensively, (b) designing a social system or learning environment, namely situations or rules that apply in the Model, (c) designing principles the principle of reaction, which is a picture for the teacher about how to respond and respond to the behaviors shown by students while participating in learning, and when the teacher can intervene student in learning, (d) determine support system, namely conditions needed for the learning model that is designed can be implemented well, for example learning systems, learning tools, and learning facilities, and (e) compiling the impact of learning, both instructional impact and accompanist. The realization of the Model obtained at this stage, then named the Prototype-1 Model. The prototype-1 model was then assessed and provided input by the experts for improvement, this activity continued until a valid model was obtained. In this study, the assessment occurred twice, namely 
Prototype-I and Prototype-II. The Prototype-II finally be the Valid model named GCLC-2C Model.

\subsection{Expert validation of models}

Experts in Learning, Chemistry Education, and Chemists (Green Chemistry) were contacted and asked to be willing to participate in this study as expert researchers. The role of expert researchers is to ensure the content validity of the model as an independent evaluation. They were given a portfolio that included (1) a description of the theoretical background on which the model was developed, (2) the first draft of the syntax of the model that had been developed, (3) an evaluation sheet, where experts were asked to provide their opinions related to the rational development of the model, the adequacy, completeness, and clarity of the theory, and the syntax of the proposed model. A detailed summary of the comments by the expert panel and the respective decisions made accordingly are shown in Table 1.

\section{Result and Discussion}

\subsection{Research result}

The Green Chemistry Learning Model Based on Lesson Study Learning Community produced in this research is called the GCLC-2C (Green Chemistry Learning Comprehensive Model by Collaborative and Collegialities). The resulting model is a product of Research and Development (R\&D). The syntax which is a criterion for a model can be seen in Table 1 .

Table 1. Teacher and student activities at each phase in the GCLC-2C Model syntax.

\begin{tabular}{|c|c|c|}
\hline Phase & Teacher's Activities & Students' Activities \\
\hline Phase 1 & $\begin{array}{l}\text { 1. The teacher submits the } \\
\text { Chemistry Lesson and relates the } \\
\text { material to the possible }\end{array}$ & $\begin{array}{l}\text { 1. Listen carefully to the } \\
\text { material delivered by the } \\
\text { teacher }\end{array}$ \\
\hline $\begin{array}{l}\text { Submission of } \\
\text { Information / } \\
\text { Chemistry Lesson } \\
\text { by linking the } \\
\text { possibility of } \\
\text { Environmental } \\
\text { Problems }\end{array}$ & $\begin{array}{l}\text { environmental problems of the } \\
\text { process or chemical product } \\
\text { (Green Chemistry) } \\
\text { 2. The teacher conveys } \\
\text { environmental problems related } \\
\text { to the material being taught } \\
\text { (chemical problems due to } \\
\text { neglect of green Chemistry) }\end{array}$ & $\begin{array}{l}\text { 2. Respond to the teacher's } \\
\text { explanation either by } \\
\text { asking questions, giving } \\
\text { advice, or responding or } \\
\text { giving comments }\end{array}$ \\
\hline
\end{tabular}




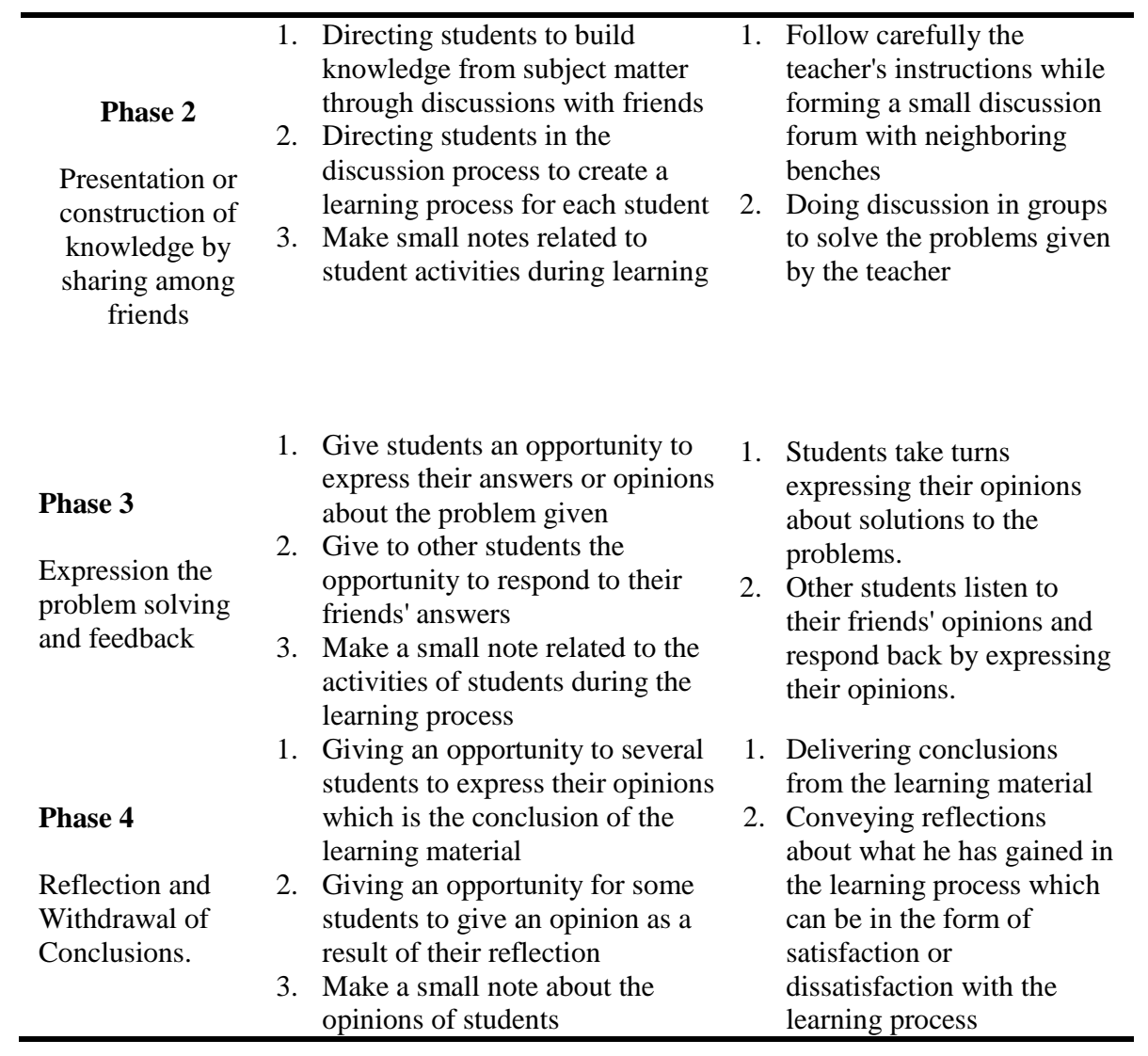

This model has met the quality of a product, which has met the validity criteria based on expert judgment. Validation of the GCLC-2C model begins with the presentation of the manuscript (GCLC-2C Model Book) along with the GCLC-2C Model assessment sheet to five experts and practitioners. Overall validator assessment of all aspects of the GCLC-2C Model is in the valid category. The results of the assessment, analysis, and revision of the GCLC-2C Model are presented as in Table 2.

Table 2. Results of Expert Evaluation of the GCLC-2C Model

\begin{tabular}{|c|c|c|c|c|c|c|c|}
\hline \multirow{2}{*}{$\begin{array}{c}\text { Aspects of the GCLC-2C Model } \\
\text { being assessed }\end{array}$} & \multicolumn{4}{|c|}{$\begin{array}{l}\text { Average Rating } \\
\text { Frequency }\end{array}$} & \multirow{2}{*}{$D(\mathbf{A})$} & \multirow{2}{*}{$\bar{\chi}$} & \multirow{2}{*}{ Ket } \\
\hline & 1 & 2 & 3 & 4 & & & \\
\hline $\begin{array}{l}\text { Rational Development of } \\
\text { Model GCLS-2C }\end{array}$ & & & 1,7 & 3,3 & 1 & 3,67 & S.Valid \\
\hline Syntax & & 0,3 & 2,3 & 2,5 & 0,95 & 3,45 & Valid \\
\hline Social System & & 0,6 & 3,0 & 1,4 & 0,88 & 3,16 & Valid \\
\hline $\begin{array}{l}\text { Principle of Reaction (Teacher } \\
\text { Behaviour) }\end{array}$ & & 0,4 & 3,0 & 1,6 & 0,95 & 3,25 & Valid \\
\hline Supporting System & & & 3 & 2 & 1 & 3,40 & Valid \\
\hline
\end{tabular}


Instructional and Accompaniment

Impacts

Learning Implementation

Learning Environment and

Management Tasks

Evaluation

\section{Average Total Rating}

$\begin{array}{ccc} & 3,2 & 1,8 \\ 0,5 & 3,2 & 1,3 \\ 0,8 & 3,3 & 1,0 \\ 0,8 & 3,8 & 0,5 \\ & & \end{array}$

DESCRIPTION

A

\begin{tabular}{|c|c|}
\hline 1 & 3,36 \\
\hline 0,87 & 3,17 \\
\hline 0,90 & 3,05 \\
\hline 0,80 & 2,95 \\
\hline 0,93 & 3,27 \\
\hline \multicolumn{2}{|c|}{ Rating Frequency } \\
\hline B & C \\
\hline
\end{tabular}

General assessment of the GCLC-2C Model

5

Table 2 shows that overall aspects of the GCLC-2C Model assessed by experts and practitioners are in the valid category, even though there is one aspect considered to be very valid, namely the rational aspects of the GCLS-2C Model Development. In addition, the general assessment of the GCLC-2 C Model for all experts gave good marks (B).

\subsection{Discussion}

The discussion and discussion of the achievements of the Model development research and its tools are stated in detail as follows. Validity or validity is one measure of the quality of a product in addition to practicality and effectiveness [18]. Validity can be in the form of content validity, criteria validity, and construction validity [21]. The validity of the GCLC-2C Model is based on content validity. This is done to see the suitability of the contents and components of the model with the objectives to be achieved in connection with the development of this model. The same thing started by (Messick, 1994) that content validation aims to evaluate the extent of the contents of a product, can describe the objectives to be achieved. Content validation helps to ensure construction validation [22]. This is true, as in the content validation carried out, the assessment instrument covers all aspects of the GCLC-2C Model, in other words, the content validation instrument at the same time impacts on the completeness of the developed model. Thus, it can be concluded that the results of content validation ensure the validation of the construction.

Based on the results of the validity test analysis it can be concluded that Prototype-II (GCLC-2C Model) has all met the validity criteria based on expert judgment, with little revision. As for the things that were revised, according to experts and practitioners is to include the steps of the Lesson Study Learning community in the syntax of the model that has been developed, as a source of development of the model. This has been done, so that at each phase of the model syntax, the core Lesson Study Learning community is written and also the principles of Green Chemistry.

In the first phase, namely: the teacher motivates students through apperception by conveying the use of subject matter for daily life as well as in relation to environmental problems by chemistry that is not green. When motivating students, teachers have linked their chemistry with green chemistry. The teacher has also prepared students to learn, which is the spirit of LSLC. All students have the right to learn [23, 24, and 25].

The second phase, namely: (1) the teacher conveys chemical material and relates the material to the possible environmental problems of the chemical process or product (Green Chemistry) and (2) the teacher conveys environmental problems related to the material being taught (chemical problems due to neglect of Green Chemistry) ). The teacher's activity in this phase is to introduce the role of green chemistry in learning chemistry. This allows the construction of an environmental understanding of students through learning chemistry in green chemistry-based laboratories. The same thing was stated by [26, 27] that the understanding of 
green chemistry in the context of understanding the environment stems from learning in the laboratory.

The third, fourth and fifth phases, namely the phase that directs students to discuss and express opinions to construct their knowledge, and provide opportunities for students to reflect on themselves about what has been obtained during the learning process. In these three phases, there are also activities of the teacher making small notes about the activities of the students. This is the application of LSLC. Thus it can be concluded that a valid GCLC-2C Model that has been developed can improve learning outcomes.

In addition, the assessor also suggested that there is a description in the model that explains the relationship of the model with an attitude of caring for the environment. This is related to the purpose of developing this learning model. After going through a revision, the model has listed the relationship of the model to the attitude of caring for the environment. Although previously this was implied, it was not explicit.

The results of expert assessments that validate the GCLC-2C Model are related to the completeness of a model namely: (1) syntax, which is a sequence of activities that are also commonly called phases, (2) social systems, namely the roles of teachers and students and the types of rules that is needed, (3) the principles of reaction, namely giving the teacher an overview of how to view or respond to students' questions, (4) support systems, namely the conditions required by the model, and (5) instructional and accompaniment impacts, namely learning outcomes achieved directly by directing students to the expected goals and the accompanying impact, namely other learning outcomes produced by a learning process as a result of the creation of a learning atmosphere experienced by students directly without directing the teacher [19].

Overall the development of the GCLC-2C Model which is considered valid by experts and practitioners because the supporting components of the model are clearly listed in the GCLC2C Model book which contains (1) Introduction, includes the rational development of the model, (2) Theoretical Review of Green Chemistry Learning, covering the concepts of Learning and Learning, Green Chemistry Concepts, (3) Concepts of Lesson Study Learning Community (LSLC), (4) Concepts of Environmental Education, and (5) Overview of GCLC-2C Models and Environmental Protection, including; Model Components, Model Syntaxes, Social Systems, Model Reaction Principles, and Model Support Systems, and Instructional Impacts and Model Accompaniment.

\section{Conclusions}

The process of developing the GCLC-2C Model goes through four stages, the first three stages, namely: (a) the initial investigation stage, (b) the Design Stage, and (c) the Realization Phase produces Prototype I1 of the GCLC-2C Model, while the fourth stage of the development process, namely the stage Testing, Evaluation, and Revision produces a valid, practical and effective GCLC-2C Model. The GCLC-2C Model trial was conducted through Learning in the laboratory (Practicum) by applying the syntax of this model, which included: (a) Submitting Learning Objectives and Motivating students, (b) Submission of Information / Material Chemistry by linking the possibility of Environmental Problems, (c) Presentation or construction of Knowledge by sharing among friends, (d) Disclosure of problem solving and feedback, (e) Reflection and Drawing Conclusions. 
The results of the development were obtained by the Lesson Study Learning Community (Model GCLC-2C) Green Chemistry Learning Model which was valid based on expert judgment. In addition, the GCLC-2C Model as outlined in the form of a Model book has components, which include: Introduction which contains rational and supporting theories, syntax, social systems, and reaction principles, instructional and accompanying impacts and is accompanied by instructions for use.

\section{References}

[1] Du Pisani, J. A.: Sustainable development - historical roots of the concept. Environmental Sciences, Vol. 3(2). pp. 83-96 (2006)

[2] do Lago, A. A. C.: Stockholm, Rio, Johannesburg: Brazil and the Three United Nations Conferences on the Environment. In Environment. Brazil: Brasília : Instituto Rio Branco; Fundação Alexandre de Gusmão, (2009)

[3] Steinfield, J. I.: Review Book Green Chemistry: Theory and Practice, by Paul T. Anastas and John C. Warner. Oxford, UK: Ox- ford University Press, 1998, 135+xi pages, ISBN 0-19-850234-6, Green Chemistry: Frontiers in Benign Chemical Synthesis and Processes, ed. by Paul T. A. Journal of Industrial Ecology. (1998)

[4] Anastas, P., \& Eghbali, N.: Green Chemistry: Principles and Practice. Chemical Society Reviews, Vol. 39. pp. 301-312 (2010)

[5] Collins, T. J.: From the chemistry of responsible environmentalism to environmentally responsible chemistry Introducing Green Chemistry in Teaching and Research. Journal of Chemical Education, Vol. 72(11). pp. 965-966 (1995)

[6] Hjeresen, D. L., Boese, J. M., \& Schutt, D. L.: Green Chemistry and Education. Journal of Chemical Education. Vol. 77(12). pp. 1543. (2000)

[7] Braun, B., Charney, R., Clarens, A., Farrugia, J., Kitchens, C., Lisowski, C., ... O 'neil, A.: Completing Our Education. Green Chemistry in the Curriculum. Chemical Education Today Journal of Chemical Education@BULLET @ BULLET Www.JCE.DivCHED.Org, 83(8) (2006)

[8] Karpudewan, M., Ismail, Z. H., \& Mohamed, N.: The integration of green chemistry experiments with sustainable development concepts in pre-service teachers' curriculum: Experiences from Malaysia. International Journal of Sustainability in Higher Education. Vol. 10(2). pp. 118-135 (2009)

[9] Anastas, P. T., \& Beach, E. S.: Changing the Course of Chemistry (2009)

[10] Karpudewan, M., Hj Ismail, Z., \& Mohamed, N.: Green Chemistry: Educating Prospective Science Teachers in Education for Sustainable Development at School of Educational Studies, USM. Journal of Social Sciences. Vol. 7(1). pp. 42-50 (2011)

[11] Vilches, A., \& Gil-Pérez, D.: Creating a Sustainable Future: Some Philosophical and Educational Considerations for Chemistry Teaching. Science and Education. Vol. 22(7). pp. 1857-1872 (2013)

[12] Andraos, J., \& Dicks, A. P.: Green chemistry teaching in higher education: a review of effective practices. Chem. Educ. Res. Pract. Chem. Educ. Res. Pract, Vol. 13(13). pp. 69-79 (2012)

[13] Graham, K. J., Jones, T. N., Schaller, C. P., \& McIntee, E. J.: Implementing a student-designed green chemistry laboratory project in organic chemistry. Journal of Chemical Education. Vol. 91(11). pp. 1895-1900 (2014)

[14] Karpudewan, M., Roth, W.-M., \& Ismail, Z.: The Effects of “"Green Chemistry”" on Secondary School Students' Understanding and Motivation. Asia-Pacific Edu Res. Vol. 24(1). pp. 35-43 (2015)

[15] Auliah, A., Mulyadi, \& Muharram.: Development of Integrated Analysis Practicum Module based on Green ChemistryNo Title. In G. D. Dirawan (Ed.), The 2nd International Conference on Education, Science, and Technology (ICEST 2017). Makassar. pp. 109-111 (2017)

[16] Nurbaity.: JURNAL RISET PENDIDIKAN KIMIA Vol. 1, No. 1 (2011) PENDEKATAN GREEN CHEMISTRY SUATU INOVASI DALAM PEMBELAJARAN KIMIA BERWAWASAN LINGKUNGAN. JURNAL RISET PENDIDIKAN KIMIA. Vol. 1(1). pp. 13-21 (2011) 
[17] Burmeister, M., Rauch, F., \& Eilks, I.: Education for Sustainable Development (ESD) and chemistry education. Chemistry Education Research and Practice. 13(2). pp. 59-68 (2012)

[18] Akker, J. van den, Brenda, B., Kelly, A. E., Nieveen, N., \& Plomp, T.: Educational Design Research. In P. \& Tjeerd \& N. Nieveen (Eds.), Educational Design Research (2013)

[19] Joyce, B., Weil, M., \& Calhoun, E.: Models of Teaching. Model-Model Pengajaran. Terjemahan (Kedelapan). Yogyakarta: Pustaka Pelajar (2011)

[20] N. Nieveen, I. J. V. den A.: Prototyping to reach product quality. In \& T. P. (Eds. . In J. van den Akker, R. Branch, K. Gustafson, N. Nieveen (Ed.), Design approaches and tools in education and training (pp. 125-136).). Dordrecht, the Netherlands: Kluwer Academic Publishers. (1999)

[21] Messick, S.: Foundations of validity: Meaning and consequences in psychological assessment. In European Journal of Psychological Assessment (Vol. 10) (1994)

[22] Yaghmale, F.: Content validity and its estimation. Journal of Medical Education. Vol. 3(1). pp. 25-27 (2003)

[23] Lewis, C.: Brief Guide to Lesson Study. Lesson Study: A Handbook for Teacher-Led Improvement of Instruction. pp. 1-5 (2002)

[24] Dudley, P.: Teacher learning in Lesson Study: What interaction-level discourse analysis revealed about how teachers utilized imagination, tacit knowledge of teaching and fresh evidence of pupils learning, to develop practice knowledge and so enhance their pupils' lea. Teaching and Teacher Education. Vol. 34. pp. 107-121 (2013)

[25] Saito, E., Sato, M., \& Consultant, F.: Lesson study as an instrument for school reform: A case of Japanese practices. Management In Education. Vol. 26(4). pp. 181-186 (2012)

[26] Wardencki, W., Curylo, J., \& Namiesnik, J.: Green chemistry-current and future issues. Polish Journal of Environmental Studies. Vol. 14(4). pp. 389-395 (2005)

[27] Santosa, S. J.: Kim.Hijau Sbg Pilar Utama Pemb Lestari.pdf, Yogyakarta (2008) 